\title{
ANALYSIS OF THE ENERGY SYSTEM BALANCE EFFICIENCY PROVIDED WITH THE DIFFERENT GROUPS OF GENERATING PLANTS
}

\author{
O. Maksymova ${ }^{1}$, M. Maksymov ${ }^{2}$, V. Silina ${ }^{3}$, A. Orischenko ${ }^{4}$ \\ ${ }^{1}$ Odessa National Academy of Food Technologies, Odessa, Ukraine \\ ${ }^{2,4}$ Odessa National Polytechnic University, Odessa, Ukraine \\ ORCID: ${ }^{1}$ 0000-0003-3986-0991, ${ }^{2}$ 0000-0002-5626-5265, ${ }^{3} 0000-0002-7837-6660,{ }^{4} 0000-0001-7556-7763$ \\ E-mail: ${ }^{1}$ m.oxana.b@gmail.com, ${ }^{2}$ maximov.agro@gmail.com, ${ }^{3}$ vikuskaxxx@gmail.com, ${ }^{4}$ orischenkoa@gmail.com
}

Copyright (C) 2017 by author and the journal "Automation technological and business - processes".

This work is licensed under the Creative Commons Attribution International License (CC BY).

http://creativecommons.org/licenses/by/4.0/

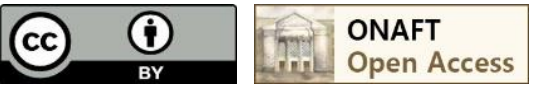

Abstract: Currently methods of efficiency analysis are being developed and applied, based on optimization tasks for various types and modes. Usually, the optimization criterion for these objectives is efficiency that can be calculated in various ways, for which there is no concurrent views. The target function based on minimization of given cost that allows comparing options with the same useful effect is used to search for the best indicators of power plants operated within the system. Marginal costs on the amount of difference in the useful effect are introduced to the target function in case of various useful effects. The criterion of selecting the best power plant from an economic point of view is the difference between the reduced costs of the considered and the basic options, but this approach does not allow using the results for long-term projections. Such approach depends on the situation and does not reflect the real costs. The value of the target function to optimize the effectiveness of the technical-economic method is not "marginal" and does not allow assessing the impact of various processes on the overall option efficiency. Therefore, the development of the efficiency criterion that considers the changing needs of the energy system is relevant for analyzing the power plant.

Аннотация: В настоящее время разрабатываются и применяются методы анализа эффективности, в основу которых положены задачи оптимизации различных типов и видов. Как правило, критерием оптимизации этих задач является эффективность, которая может быть рассчитана различными способами, по которым нет окончательно сформулированной единой точки зрения. Для поиска наилучших показателей энергетических установок, эксплуатирующийся в системе, используют иелевую функиию, в основе которой лежит минимизация приведенных затрат, которая позволяет сопоставить варианты, имеющие одинаковый полезный эффект. В случае различного полезного эффекта в целевую функцию вводят замыкающие затраты на величину разницы в полезном эффекте. Критерием выбора наилучшей с экономической точки зрения установки является разность приведенных затрат рассматриваемого и базового вариантов, но такой подход не позволяет использовать результать для долгосрочньхх прогнозов. Этот подход зависит только от конъюнктуры и не отражает реальных затрат. Величина иелевой функции оптимизации эффективности технико-экономического метода не «предельна» и не позволяет оценить влияние тех или иных прочессов на общую эффективность варианта. Поэтому разработка критерия эффективности, учитывающего изменяющуюся потребность энергетической системы, для анализа энергетической установки является актуальной.

Keywords: thermal power plant, operating efficiency, target optimization function, marginal energy costs.

Ключевые слова: тепловая энергетическая установка, эффективность эксплуатации, целевая функция оптимизации, замыкающие затраты энергии.

\section{Introduction}

Given the current state of the Ukrainian energy market, the reliable, efficient and economically sound operation of generating plants remains an important mean to ensure sovereignty of our state. Many internal disturbances effect the power plants when operating in the steady state mode of operation. Quantity of external disturbances increase when plants areoperatedas part of a daily load cycle, which leads to a change of technological parameters values and the condition of the equipment responsible for safe operation. Therefore, according to certain rules, the balance of plants that perform certain 
functions while maintaining the balance of generation and consumption in the system, is being formed in the power system of Ukraine.

The following numbers of plants are being currently operated in Ukraine: 13 HPPs and 3 PSPs (table. 1), 4NPPs (table. 2), 15 TPP(Tab. 3) [1, 2].

Table 1 - Operating HPPs and PSPs in Ukraine

\begin{tabular}{|l|l|l|}
\hline Name of HPP & The number of power units & $\begin{array}{l}\text { The total capacity, } \\
\text { MW }\end{array}$ \\
\hline Kievskaya & 6 & 388,8 \\
\hline Kyivskaya PSP & 6 & 235,5 \\
\hline Kanevskaya & 24 & 444 \\
\hline Kremenchugskaya & 12 & 692 \\
\hline Srednednerpovskaya & 8 & 352 \\
\hline Dniprovskaya & 18 & 1569 \\
\hline Kakhovskaya & 6 & 351 \\
\hline Dniestrovskaya & 6 & 702 \\
\hline Dniestrovskaya - & 3 & 40,8 \\
\hline Dniestrovskaya PSP & 3 & 972 \\
\hline Tashlykskaya PSP & 6 & $302 \mathrm{t} / 433 \mathrm{n}$ \\
\hline Alexanderovskaya & 2 & 11,5 \\
\hline Suharabovskaya & 3 & 0,3 \\
\hline Tereblya-Ritskaya HPP & 3 & 27 \\
\hline Shishatskaya HPP & 1 & 0,525 \\
\hline
\end{tabular}

Table 2 - Operating NPP in Ukraine

\begin{tabular}{|l|l|l|}
\hline Name of NPP & The number of power units & $\begin{array}{l}\text { The total capacity, } \\
\text { MW }\end{array}$ \\
\hline Zaporozhskaya & 6 & 6000 \\
\hline Yuzhnoukrainskaya & 3 & 3000 \\
\hline Khmelnytskaya & 2 & 2000 \\
\hline Rovnenskaya & 4 & 2880 \\
\hline
\end{tabular}

Table 3 - Operating TPP in Ukraine

\begin{tabular}{|l|l|l|}
\hline Name of TPP & The number of power units & The total capacity, MW \\
\hline Uglegorskaya & 3 & 3600 \\
\hline Zaporozhskaya & 4 & 1250 \\
\hline Burshtynskaya & 12 & 2400 \\
\hline Krivorozhskaya & 10 & 2820 \\
\hline Zmievskaya & 10 & 2200 \\
\hline Zmievskaya & 10 & 2200 \\
\hline Starobeshevskaya & 13 & 2275 \\
\hline Tripololskaya & 6 & 1800 \\
\hline Ladyzhynskaya & 6 & 1800 \\
\hline Kurakhovskaya & 9 & 1460 \\
\hline Zuevskaya & 4 & 1270 \\
\hline Luganskaya & 8 & 1360 \\
\hline Pridneprovskaya & 7 & 2400 \\
\hline Slovjanskaya & 2 & 880 \\
\hline Dobrotvorskaya & 5 & 600 \\
\hline Mironovskaya & 1 & 115 \\
\hline
\end{tabular}

According to data obtained in the year 2016, the total power generation from NPP figures up to 80,95 billion KWh, TPP sand CHPP generated 49 billion 902,3 million KWh and 6 billion 709,3 million KWh respectively, HPPs and PSPs - 6 billion 576,8 million $\mathrm{kWh}$. The share of NPP in power production makes up to 52.3\%, the TPP and CHPP - 36,6\%, HPP and PSP $5,9 \%$, municipal CHPP and block-stations - $4.2 \%$, alternative sources - $1 \%$.

Power system loads per day varies depending on the load of currently connected users. Soit appears rather complicated task for the best load distribution between power plants of various types with regard to their maneuverability. Therefore, a joint 
analysis of the energy system with the operating units within it, taking into account the changing needs of the energy system, makes an urgent task.

2. The purpose of the article and tasks to achieve it

The purpose of this article is to conduct a joint analysis of the power system with various power plants working together in the power system, to ensure its demands with a minimum primary energy sources application.

To achieve the goal,it is necessary:

- to consider the advantages and disadvantages of generating plants in the formation of primary cost of electric energy;

- to analyze and determine the energy system effectiveness;

- toconduct a model test aimed to identify performance indicators

3. Analysis of generating plants'advantages and disadvantages in the formation of cost of electric energy

Fig. 1 shows an example of the daily load curve with morning and evening peaks [3]. A daily gap in power consumptionis seen between them. The active load power relative towards its maximum value is represented under thevertical axis. Three main parts are on the load curve: the base, intermediate and peak. The basic part of the curve involves the minimum power generation. This part of the curve is represented by NPPs, which power regulation is complicated for technological and safety reasons; CHPPs (combined heat and power plants), the electric power of which is rigidly linked to the production of thermal power and therefore cannot vary widely; HPPs, provided there is sufficient water in the storage reservoir, particularly during floods, to avoid water discharge except generating units. This can be added by HPPs, where water pass is stable through the necessary navigation conditions and sanitary requirements.

Intermediate load isa part of the curve following the basic one. Intermediate load is covered by CPPs, which need to work in a stable mode most of the time during the day. On the one hand, this happens because power generation at CPPs is not associated with the thermal energy production, and, on the other hand, the frequent start and shut down operations of the units are impossible. CPP needs a few hours to start the plant, due to the need for metal components of the turbine and generator to be smoothly heated. In Fig.1,CPPpowertwice changes dramatically: at 7 a.m. and at 11 p.m. The attraction of powerful CPPs to the regulation of power is a necessary measure, stipulated by a large share of TPPs in the aggregated capacity of the IPS. Some HPPs also operate within the intermediate part.

Peak load is the upper part of the load curve, located at the level of maximum capacity. The most maneuverable power plants are involved in covering the peak part of the load - it involves HPPs and PSPs. In the night power gap on the curve, PSPs operate in the pump mode, accumulating water in the upper head basin. During high loads, PSPs operate in turbine mode, generating power into the energy system due to the water supply accumulated during the night. The hydraulic units can be unloaded up to $100 \%$

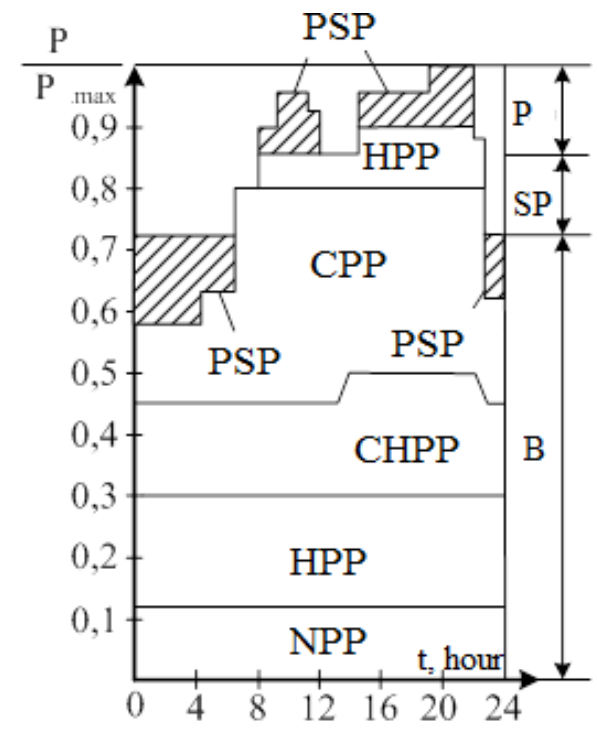

Fig. 1 - Daily power system load curve

The following reasons influence theelectric load curve and the frequency quality of electricity:

- TPPs of Ukraine have run out their term, which is 30 years;

- intensive wear of the boiler heating surfaces;

- large and long repair costs of the equipment do not allow working steadily in the intermediate part of the power load curve;

- lack of funds for modernization of TPPs equipment and for purchase of fuel;

-use of HPP and PSP not only for covering peak loads, but also for compensatingcapacity in the system due to the fact that some TPPs has been stopped.

The daily start and shut down operations of power units with a capacity of $160-800 \mathrm{MW}$ are not always feasible because of the adverse starting characteristics of the equipment and the casing designed for the basic modes of operation. Power reduction of $300 \mathrm{MW}$ or more for up to seven hours, which corresponds to the night power gap, is economically more profitable of those powers units stopsat the same time [4]. Technical and economic performance indicators of boilerschange at 
http://www.atbp.onaft.edu.ua/

systematic involvement of TPPs in regulating the load curve. Reducing the number of operation hours of the power unit results in a significant change of the specific fuel consumption.

High maneuverability is a feature of HPPs and PSPs. So, the start of generating units from a stop position in the turbine mode with synchronization and full power makes 1-2 minutes, and when running idle - 15-30 seconds. The change of the hydraulic unit capacity or its shut down require a few seconds.

HPPs and PSPs perform the following basic tasks:

- cover the most complex peak and intermediate parts of the load curve;

- perform functions of emergency and load reserves of the power system.

The existing NPPs in Ukraine are not operated in the daily regulation mode. Maneuvering features of the WWER reactor are determined by the neutron-physical characteristics of the a.z. (active zone): by temperature coefficient of reactivity, by effectiveness of boric regulation, by regulating unit for the control and protection system effectiveness, by no stationary xenon ${ }^{135}$ Xepoisoning, by distribution of energy release in the reactor's active zone volume. When power capacity changes in the reactor, thermal stresseshappen to fuel rods due to the difference in temperature between the shell and a fuel pellet, which may cause their deformation and decompression.

Under the known market procedure,the energy market of Ukraine quarterly calculates the primary cost of electrical energy produced by plants. NPPs, producing electric power to cover base load of the network, have the lowest cost (table 4) of the electricity generated because it is determined by the cost of the plant construction but not the fuel cost, in contrast to TPPs. In addition, fuel cycle at NPP makes 4 years. The primary cost depends not only on the specific costs at the units operation, but also on the characteristics of these plants'maneuvering features.

Table 4 - The cost of electricity

\begin{tabular}{|l|l|}
\hline Type of power plant & $\mathrm{UAH} / \mathrm{kW} \cdot \mathrm{year}$ \\
\hline NPP & 0,47 \\
\hline TPP & 1,323 \\
\hline SOLAR PP & 0,97 \\
\hline CHPP & 1,62 \\
\hline HPP & 0,59 \\
\hline
\end{tabular}

It becomes clear from Table 5, which contains the maneuvering characteristics of various power plants types, that the technical load minimum of NPP is $85 \%$, and for TPP $-70 \%$. Comply with the regulations, the power speed reduction of WWER-1000 from $100 \%$ to $80 \%$ amounts to $1 \%$ for $6 \mathrm{~min}$, and the rate of power increase from $80 \%$ to $100 \%$ amounts to $1 \%$ per minute [5].

Table 5 - Characteristics of maneuverable properties of various power plant types

\begin{tabular}{|l|l|l|l|l|}
\hline \multirow{2}{*}{ PP type } & $\begin{array}{l}\text { Technical } \\
\text { minimum, } \\
\%\end{array}$ & Control range, \% & Full power time, minutes \\
\cline { 4 - 5 } & $85-90$ & & After shut down & From hot position \\
\hline NPP & $70-80$ & $10-15$ & $390-660$ & 60 \\
\hline Powerful TPP & 0 & $20-30$ & $90-180$ & $20-50$ \\
\hline HEU & 0 & 100 & $15-30$ & 0,5 \\
\hline HPP & 0 & 100 & $1-2$ & $0,25-0,5$ \\
\hline PSP & 200 & $1-2$ & $0,25-0,5$ \\
\hline
\end{tabular}

The analysis of the material showed as follows:calculations, based on the given costs, are being applied to search performance indicators of power units operated within the power system, which allow comparing options with the same useful effect.In the case of various useful effects,marginal costs at the difference in the useful effect are being entered intoto the target function. Differenceof reduced costs of the considered and basic options is the criterion for selecting the best from an economic point of view group of plants. Such an approach depends on the market situation and does not reflect the real costeffectiveness.

4. Method of analysis for determination of power system efficiency

Boundary conditions should be adoptedto compare different groups of power units by values of efficiency criterion. The group of units under consideration must cover the system demands. This requirement is also metwhen determining the technical and economic indexes. The balance between different types of energy products generated changeswhen changing quantity and types of plants. Consequently, a deficiency or overproduction of this or that product must be compensated by the change in power output on marginal enterprises. In power generation it should be taken into account the need to generate a certain number of gap, base and peak electric power and therefore, to compensate an arising deficiency (or overproduction) in variants calculations of a particular type of power in the relevant enterprises. Such an approach has been proposed in [6].

When considering the plant operation in the system, it is advisable to put together the generated gap, base and peak electric power with certain amendments. In addition, in the analyzed function, it is necessary to summarize the energy spent forthe 
http://www.atbp.onaft.edu.ua/

development and manufacture of all plants with a coefficient that considers the lifetime and energy sources spent on the plant operation[7].

Efficiencycriterion, when consideringthe analyzed function of power units operating in the system, taking into account the operation ofmarginal plants and energy cost of their construction, has the following form:

$$
\eta=\frac{\sum_{j=1}^{n}\left(\sum_{i=1}^{n} E_{i s y s t}^{*}\right) \pi_{j}}{E_{p} \tau_{x x p}+(p+q) E_{s t r}\left(E_{p}(\tau)\right)+\sum_{i=1}^{n} \Delta E_{i} \mathbb{L}_{i} \varphi_{i}}
$$

where $\mathrm{E}_{\mathrm{i}, \text { syst }}^{*}$ - power needed to meet systematic demand in the $i$-th type of energy product;

$\tau_{\mathrm{j}}$ - time for the system to consume various energy products;

$\mathrm{E}_{\mathrm{p}}$-heat power of the plant in question;

$\tau_{\text {exp }}$ - operating time of the plant in question;

$\pm \Delta \mathrm{E}_{\mathrm{i}}$ - deficiency or overproduction of power needed to meet systematic demand in the $i$-th type of energy product [W];

$\Delta \tau_{\mathrm{i}}$ - time of overproduction or deficiency of the $i$-th type of energy;

$\varphi_{\mathrm{i}}$ - marginal costs of energy spent on the $i$-th type of energy product;

$\mathrm{p}$ - regulatory rate of return on the cost of energy for construction;

$q$ - factor that considers the ongoing costs of energy for environmental activities;

$\mathrm{E}_{\mathrm{str}}\left(\mathrm{E}_{\mathrm{p}}(\tau)\right)$ - energy expended in construction and ensuring ecological measures.

Summation of different power units operating in the system has been additionally introduced in the index for analysis in (1) above to determine the best structure of the system under consideration

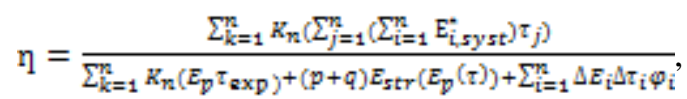

where $K$-number of power units operating in the power system.

Marginal energy consumption for electric poweris of local nature, and its size depends on the type and power generating units performance, parameters of the resulting energy carrier and type of fuel combusted.

Indicator $\varphi_{i}$ is formally formed similarly to the value of marginal costs in the economy and considersboth energy consumption on creating marginal plants and their operation, taking into account the relative value of fuel combusted there. Marginal costs of energy consumption are determined by [7]. This value takes into account the energy consumptionon construction and operation of marginal units.

$$
\varphi_{\mathrm{i}}=\alpha_{\mathrm{on}} * \alpha_{\mathrm{nl}}\left(\frac{\alpha_{\mathrm{r}}\left(\mathrm{PE}^{\alpha}+U^{\alpha}\right)}{\hbar}+b^{e} * \mathrm{E}^{f}\right)+\frac{\mathrm{PE}_{d^{\alpha}}+\mathrm{U}_{\mathrm{p} d}^{\mathrm{a}}}{\hbar}
$$

where $\alpha_{\mathrm{on}}, \alpha_{\mathrm{nl}}, \alpha_{\mathrm{r}}$ - factors that consider losses of energy for own needs, losses in networks and power reserves in the power system;

$\mathrm{p}$ - regulatory return rate;

$\mathrm{U}^{\mathrm{e}}$ - constant part of annual energy costs;

$\mathrm{E}^{\mathrm{e}}$ - specific energy consumption for the plant construction;

$E^{f}$ - energy of the fuel used in the rear plants;

$\mathrm{h}$ - annual number of maximum power usage;

$E_{d}^{e}$ - specific energy expenditure on energy distribution;

$b^{\mathrm{e}}-$ specific consumption of specific fuel.

The numerical values of coefficients $\alpha_{\mathrm{on}}, \alpha_{\mathrm{n}}, \alpha_{\mathrm{r}}$ and the calculated components of the expression (3) are shown in table 6.

Table 6 - Values of marginalpower consumption for the different energy products

\begin{tabular}{|l|l|}
\hline Type of energy products & $\begin{array}{l}\varphi \\
\mathrm{kJ} / \mathrm{kWh}\end{array}$ \\
\hline Basic electricity & 11642 \\
\hline Peak electricity & 19270 \\
\hline Gap electricity & 10055 \\
\hline
\end{tabular}

\section{A model experiment to identify performance indexes}

Three variants of different groups of power plants shown in table 7, according to expression (2) [8], have been consideredto find the best power plants combination to meet system requirements shown in figure 2 . In case if the considered power plants variants cannot ensure the balance of the system, the marginal plants have been used to close this balance. 
http://www.atbp.onaft.edu.ua/

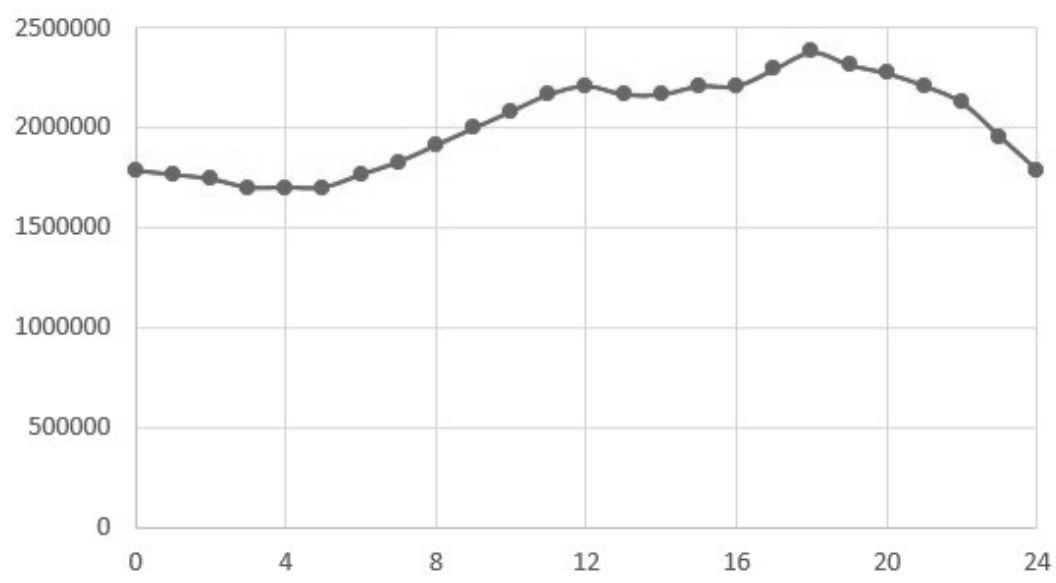

Fig. 2 - System daily need curve

Table 7 - The considered options of power plants groups

\begin{tabular}{|c|l|l|}
\hline № gr. & \multicolumn{1}{|c|}{ Types of power plants } & \multicolumn{1}{c|}{ Nominal power capacity, MW } \\
\hline 1 & 1. NPP & 1000 \\
& 2 . TPP & 800 \\
\hline 2 & 1. NPP & 1000 \\
& 2. TPP & 800 \\
& 3. HPP & 300 \\
\hline 3 & 1. NPP & 1000 \\
& 2. TPP & 800 \\
& 3. HPP & 300 \\
& 4. PSP & 300 \\
\hline
\end{tabular}

The following options have been considered for two TPP and NPP power units.

The first option. The joint TPP and NPP power units operation, on NPP capacity change from $90 \%$ to 104\%, and TPP from $100 \%$ to $110 \%$

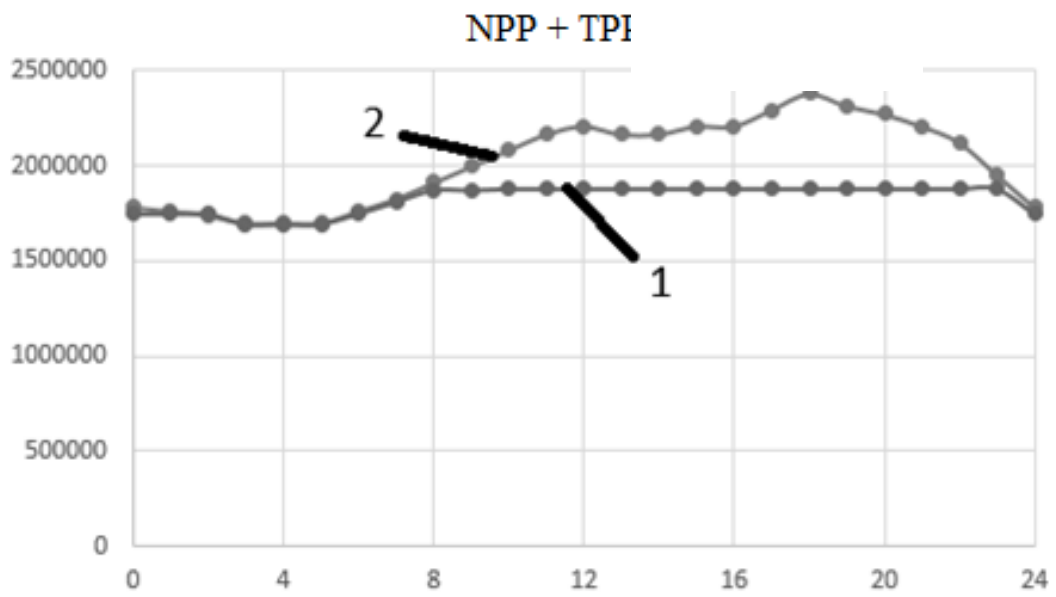

Fig. 3 - Curves of changes in electric energy production for the first option of two power plants (1) and system demand (2) per day

The curves analysis of the system demand and energy generation by plants showed that the simultaneous operation of two reporting power units does not allow, even at maneuvering and monitoring the curve, to cover system demandfor the whole time term. Even at maximum energy yield,the system demand is not covered within the period from 8 a.m. up to11 p.m. Change in performance efficiency meeting system demand for the option under consideration is presented in Figure 4.

The second option. The joint operation of NPP and TPP power units at TPP capacity change (80\% -100\%), NPP capacity $100 \%$ change. In this option (Figure 5),NPP operated on constant nominal power, and TPP was changing the power capacity depending on the system demand. Analysis of the obtained results testified to the fact that this option did not cover the system demand in the period from 7 a.m. up to 12 p.m. Figure 6 shows the performance efficiency ratio meeting the system demand; the average daily mean of this criterion is 0,2616 . 


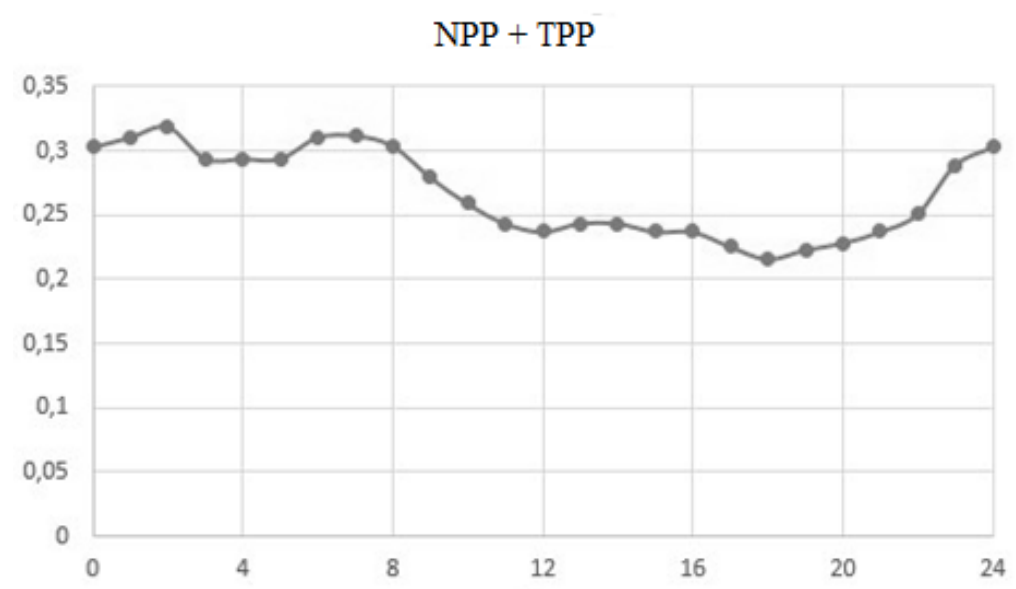

Fig. 4 - Change of performance efficiency criterion for the first option of joint operation of two power plants during the day

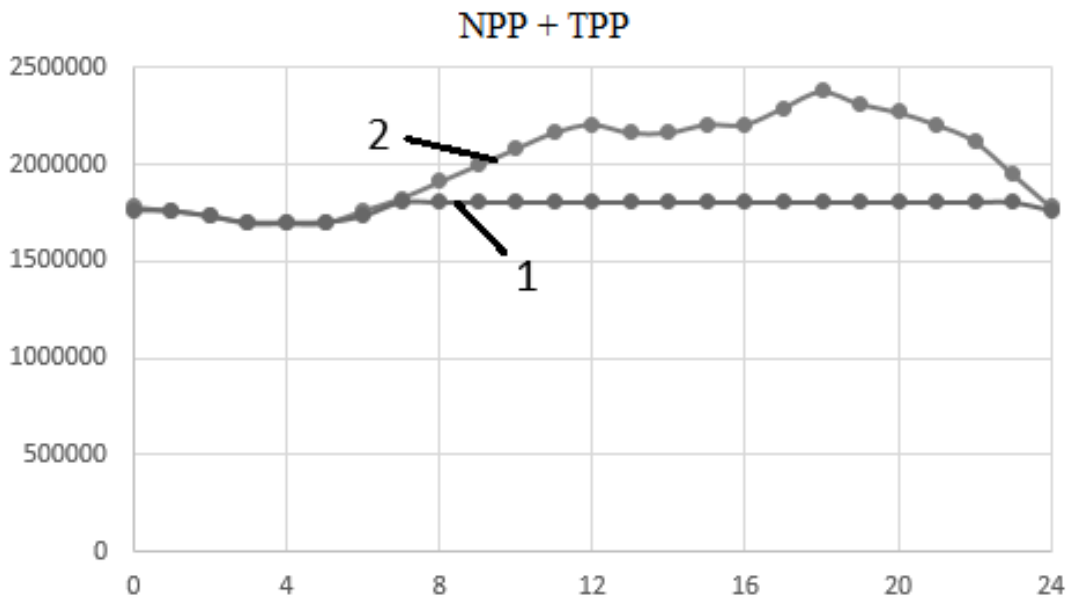

Fig. 5 - Curves of changes in electric power yield for the second option of two power units (1) and system demand (2) per day

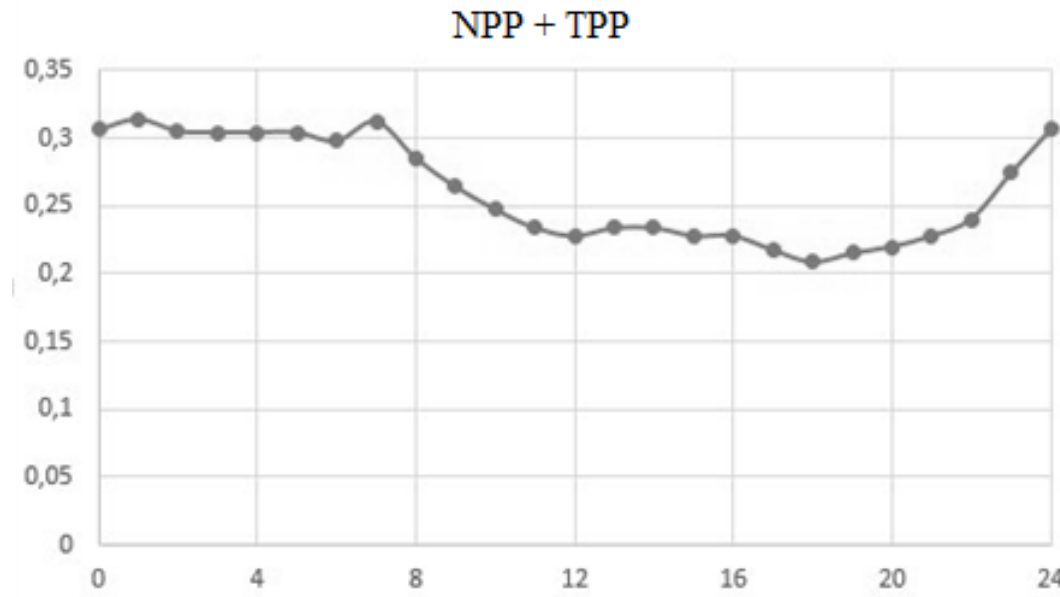

Fig. 6 - Change of performance efficiency criterion for the second option of joint operation of two power plants during the day

The third option. The joint operation of NPP and TPP power units at NPP capacity change (90\%-100\%), TPP capacity $100 \%$ change. In this option (Figure 7),TPP operates on constant nominal power, but NPP was changing the power capacity depending on the system demand. Analysis of the obtainedo results testified to the fact that this option did not cover the system demand in the period from 7 a.m. up to 12 p.m. Figure 6 shows the performance efficiency ratio meeting the system 
demand; the average daily mean of this criterion is 0,2609 .

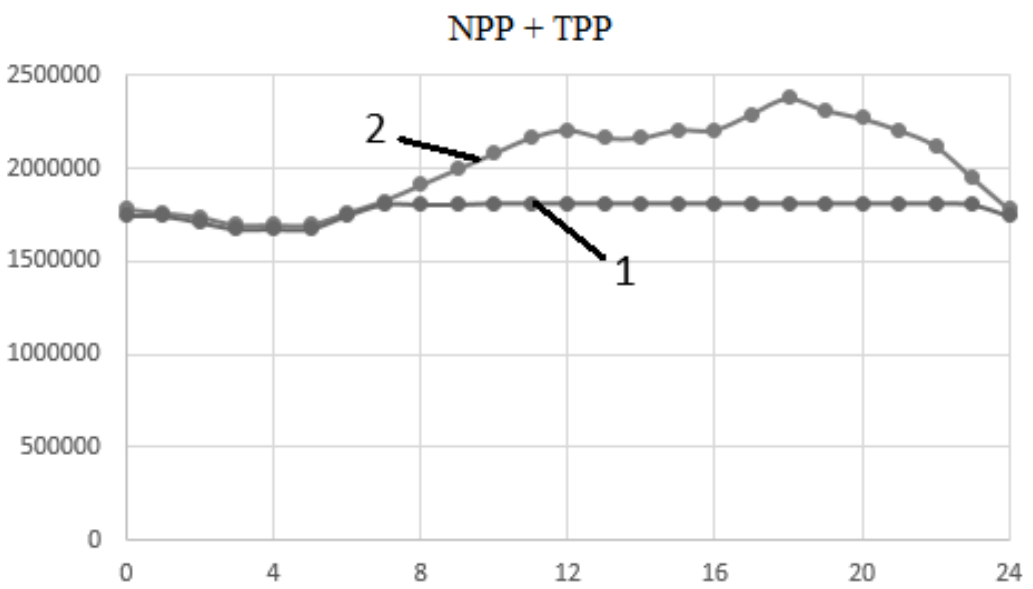

Fig. 7 - Curves of changes in electric power yield for the third option of two power units (1) and system demand (2) per day

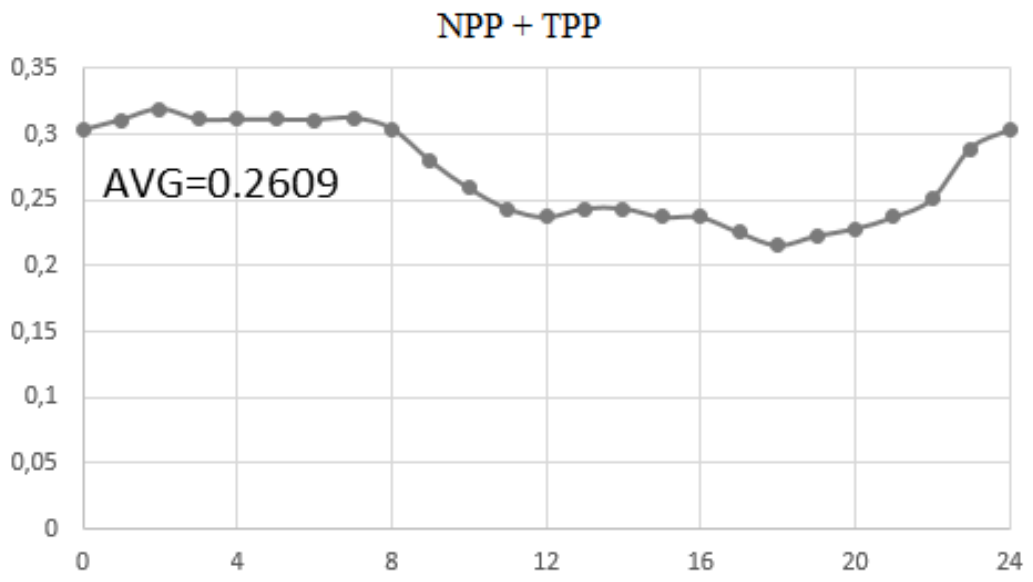

Fig. 8 - Change of performance efficiency criterion for the third option of joint operation of two power plants during the day

The analysis of the data obtained on the three options for the two operating NPP and TPP power units showed that the highest value of the efficiency criterion corresponds to the option where NPP and TPP jointly change the capacity to meet the system demand.

The following options have been considered for the three TPP, NPP and HPP power units.

The first option. The joint operation of NPP, TPP and HPP power units at TPP capacity change from $88 \%$ to $100 \%$, NPP from $73 \%$ to $104 \%$ and HPP by $100 \%$. The analysis of the obtained results for the first option of the three power units operation (Figure 9) aimed to cover the system demand has revealed the following: when NPP and TPP change their capacity, then HPP operates at its rated capacity, so the generated power energy is insufficient to cover the system demand along the whole time term. In this case, the system demand is not be covered within the period from 4 p.m up to 9 p.m.

Figure 10 shows the change of performance efficiency ratio meeting the system demand; the average daily mean of this criterion is 0,3260 .

The second option. The joint operation of NPP, TPP and HPP power units, at NPP capacity change (73-104\%), TPP-90\%, HPP-100\%.Analysis of the obtained results (Figure 11) testified to the fact that the change in NPP capacity, provided that TPP operates at $90 \%$ capacity and HPP at $100 \%$, this option does not cover the system demand within the period from 11 a.m. up to 10 p.m. Figure 12 presents the change in the performance efficiency ratio meeting the system demand; the average daily mean of this criterion is 0,3215 . 

http://www.atbp.onaft.edu.ua/

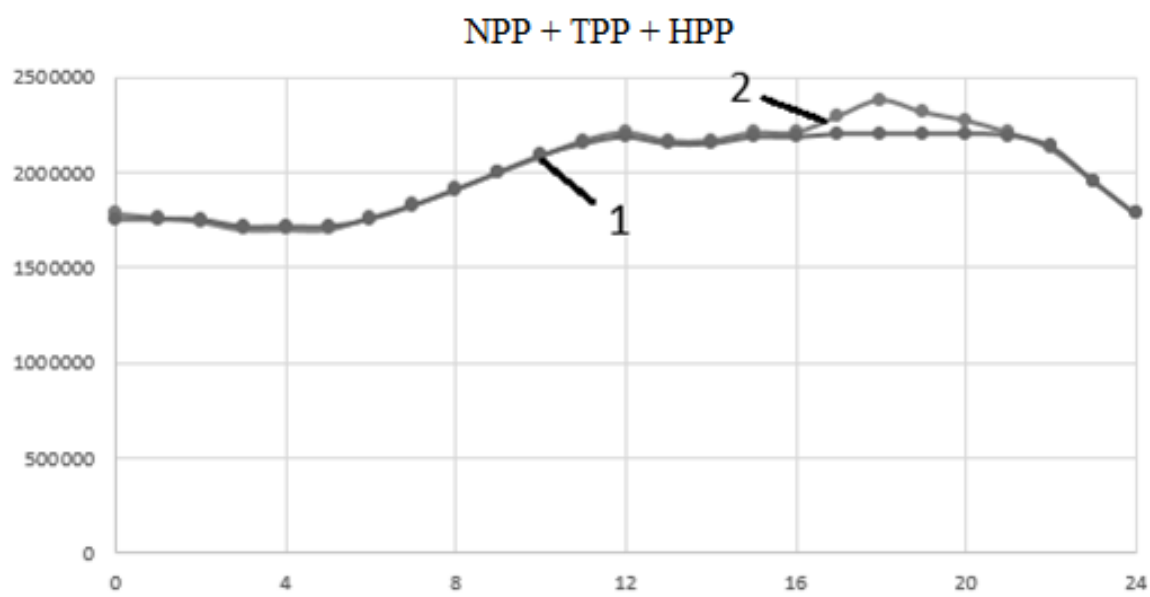

Fig. 9 - Curves of changes in electric power yield for the first option of two power units (1) and system demand (2) per day

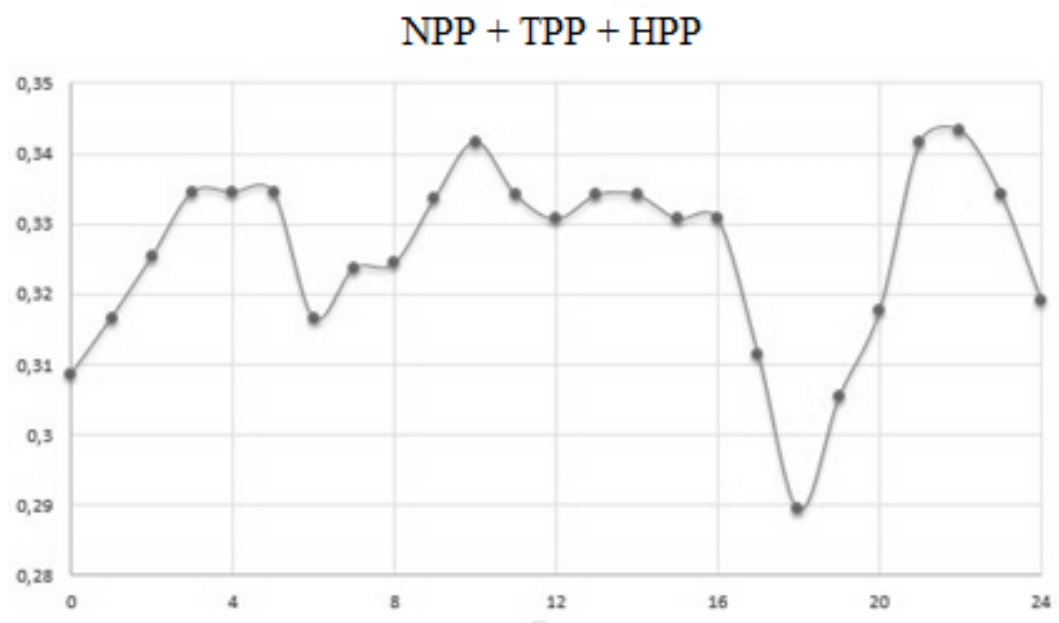

Fig. 10 - Change of performance efficiency criterion for the first option of joint operation of three power plants during the day

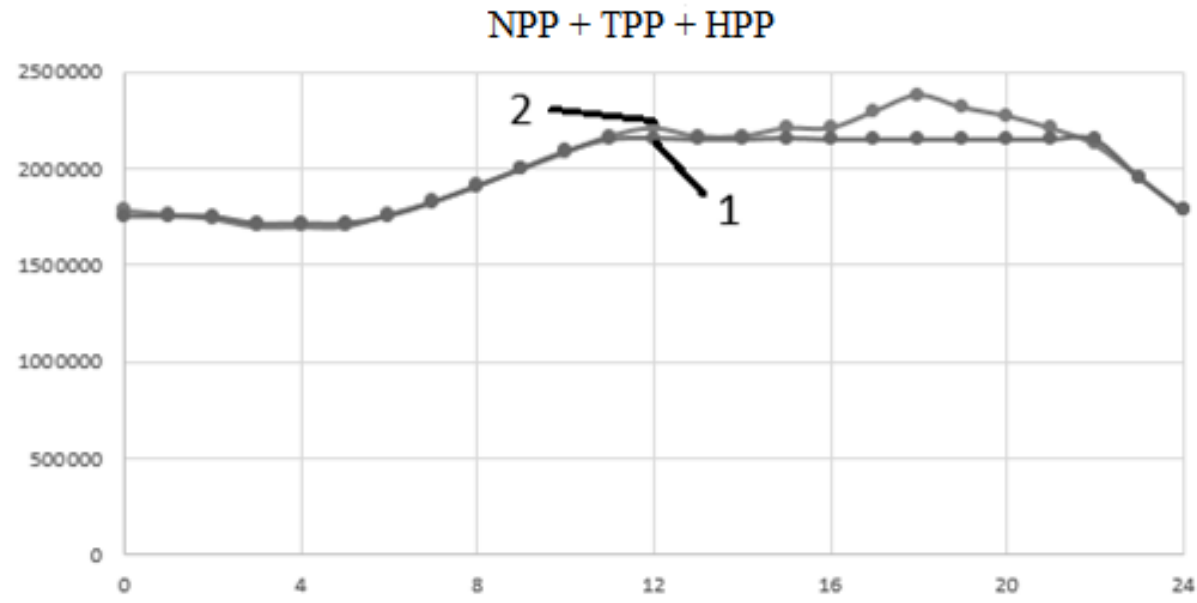

Fig. 11 - Curves of changes in electric power yield for the second option of three power units (1) and system demand (2) per day 
$\mathrm{NPP}+\mathrm{TPP}+\mathrm{HPP}$

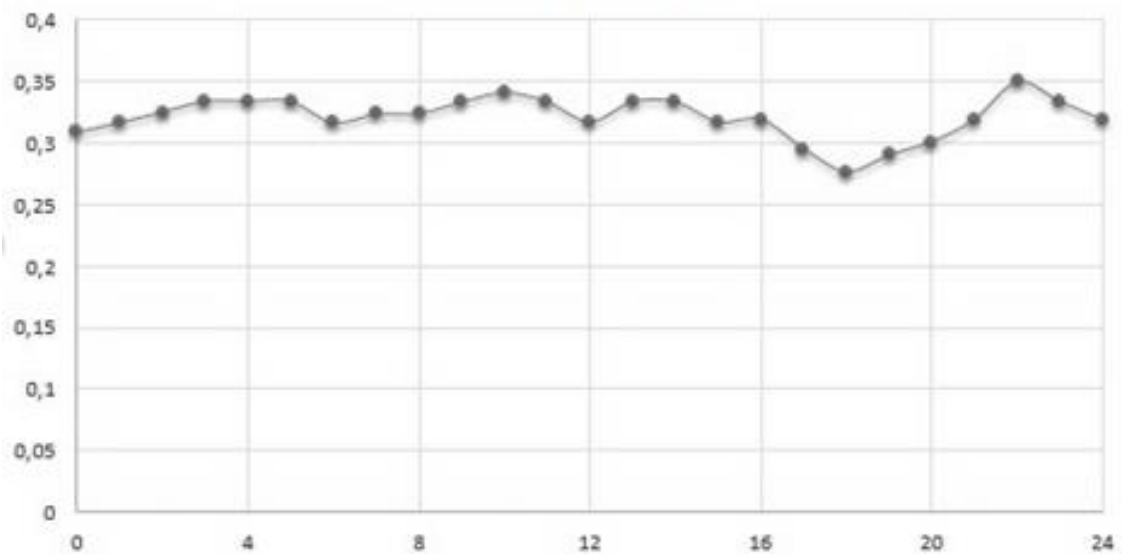

Fig. 12 - Change of performance efficiency criterion for the second option of joint operation of three power plants during the day

The third option.The joint operation of NPP, TPP and HPP power units, at TPP capacity change from $70 \%$ up to $100 \%$, HPP from $35 \%$ up to $100 \%$, NPP constantly at $90 \%$.

Analysis of the obtained results (Figure 13) has testified to the fact that in this case the power units do not cover the system demand within the period from 9 a.m. up to 11 p.m.Figure 14 presents the change in the performance efficiency ratio meeting the system demand; the average daily mean of this criterion is 0,2995 .

$$
\text { NPP + TPP + HPP }
$$

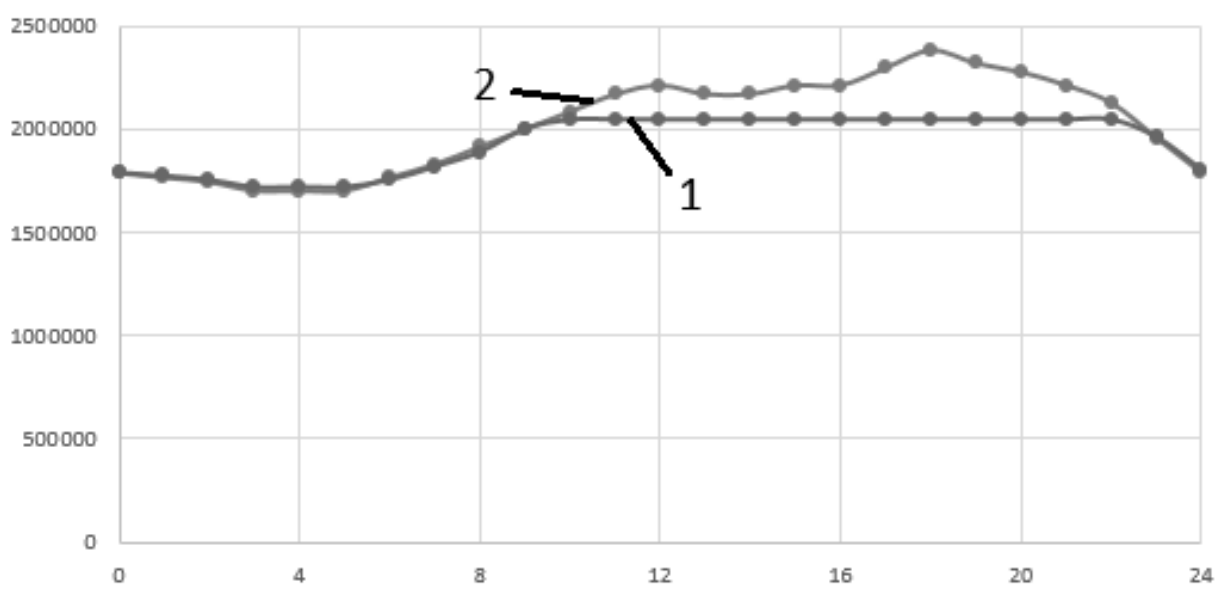

Fig. 13 - Curves of changes in electric power yield for the third option of three power units (1) and system demand (2) per day

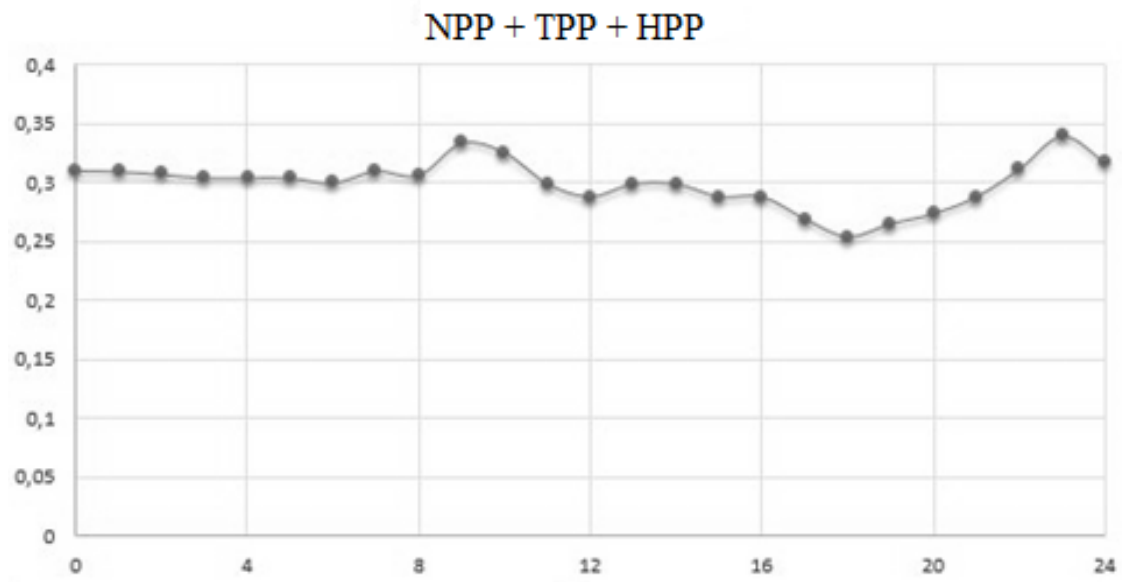

Fig.14 - Change of performance efficiency criterion for the third option of joint operation of three power plants during the day 
Analysis of the data obtained on the three options for three NPP, TPP and HPP power units showed that the highest efficiency criterion value corresponds to the option in which NPP and TPP jointly change their capacity to meet the system demand, but HPP thereat operates at the nominal mode.

The following options have been considered for the four TPP, NPP, HPP and PSP power units.

The first option. The joint operation of NPP, TPP, HPP and PSP power units at changing NPP capacity from $85 \%$ to $100 \%$, PSP from $7.5 \%$ to $80 \%$, TPP from $80 \%$ to $100 \%$ and PSP - 100\%. Analysis of the obtained results (Figure 15) testified to the fact that if NPP, TPP, PSP capacity (HPP-100\%) change, the generated electric power is sufficient to cover the system demand curve through the whole time term. There are no marginal costs in the matter under consideration. Figure 16 presents the change in the performance efficiency ratio meeting the system demand; the average daily mean of this criterion is $0,3319$.

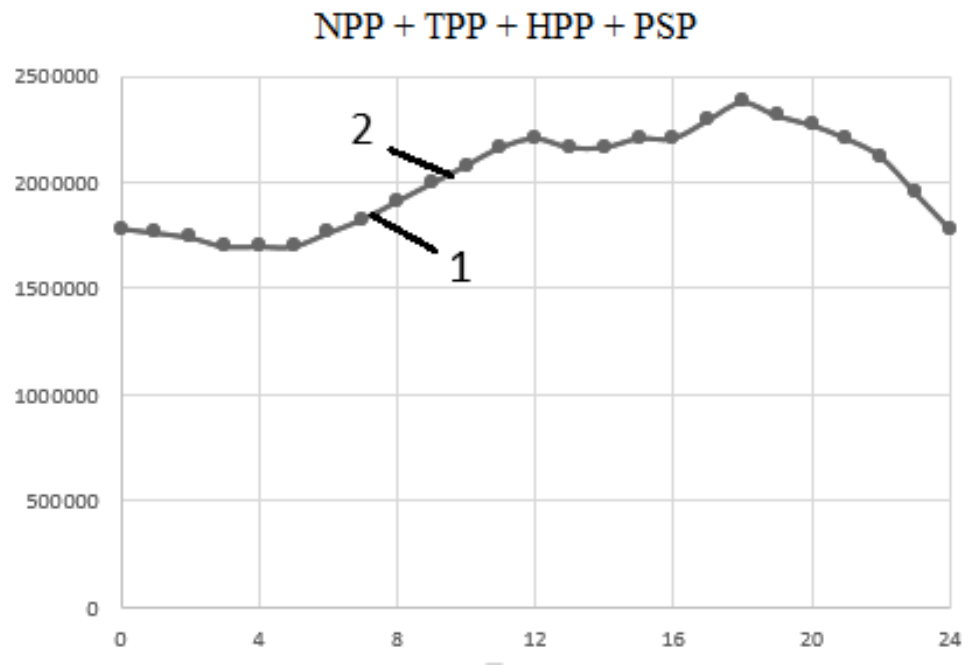

Fig. 15 - Curves of changes in electric power yield for the first option of four power units (1) and system demand (2) per day

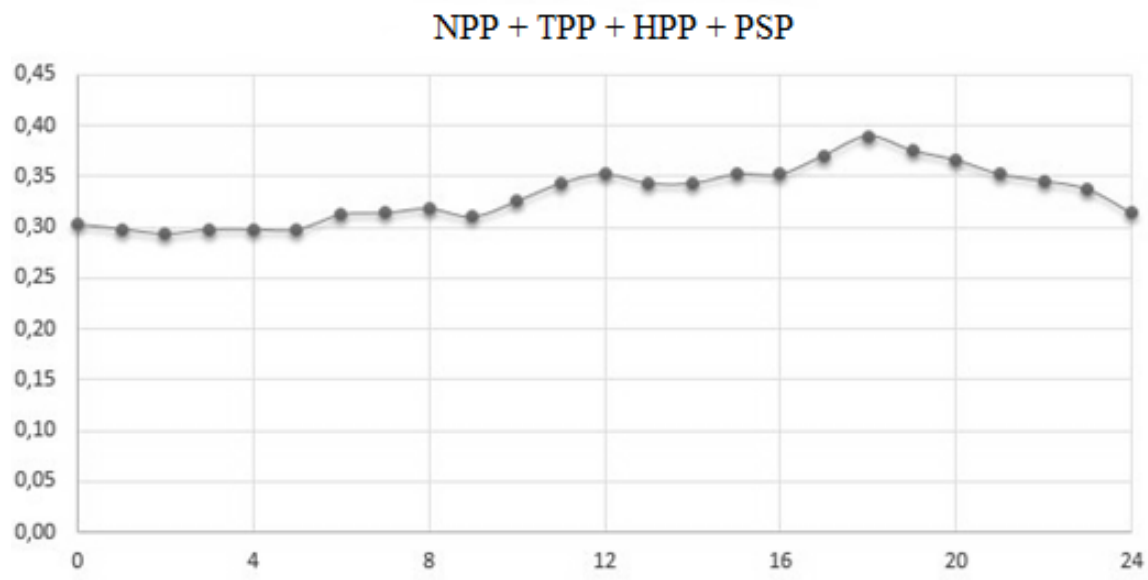

Fig. 16 - Change of performance efficiency criterion for the first option of joint operation of four power plants during the day

The second option. The joint operation of NPP, TPP, HPP and PSP power units at changing PSP capacity (7,5 - 80\%), NPP (100\%), TPP (80\%), HPP(100\%). Analysis of the obtained results (Figure 17) testified to the fact that the generated electric power is sufficient to cover the system demand curve in full through the whole time term. Figure 18 presents the change in the performance efficiency ratio meeting the system demand; the average daily mean of this criterion is $0,3235$.

6. Discussing the obtained results

The presented model experiment results showed that efficiency is of high value in the area of system demand and units power generationcurve, whichis determined by nonuse of marginal power units having the worst performance indexes. The more of the generated by power units energy coincides with the system energy consumed, the higher will be the system efficiency. Conversionefficiency of the primary energy sources into electrical energy, when changing the system demand, is more effective when maneuvering NPP and TPP capabilities are jointly used. Maneuvering in power system capacity with the help of HPP mitigates its efficiency. 


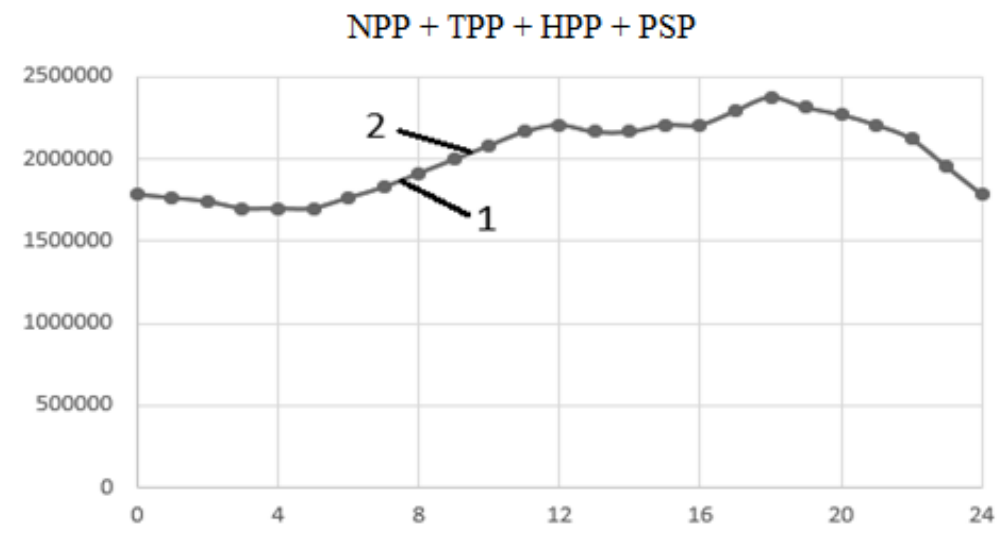

Fig. 17 - Curves of changes in electric power yield for the second option of four power units (1) and system demand (2) per day

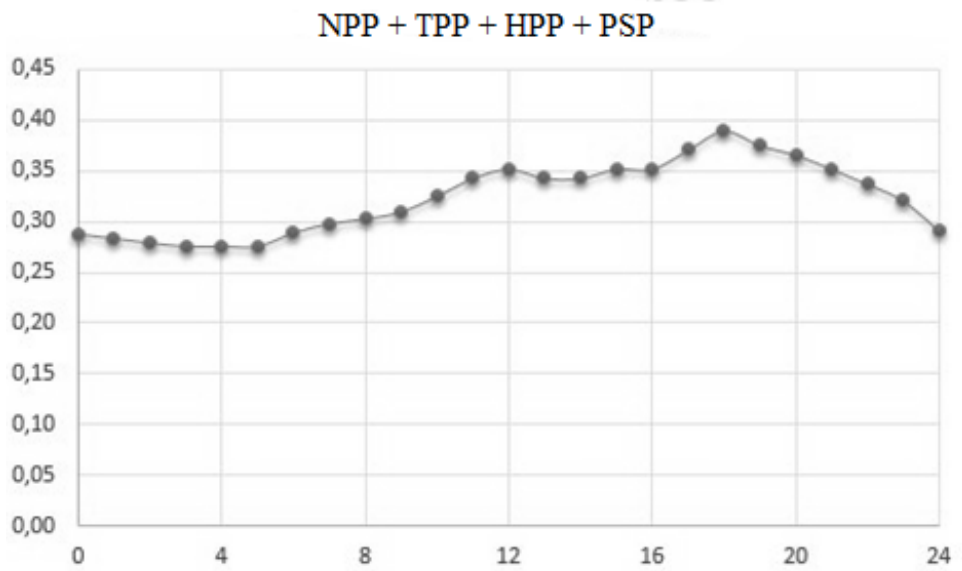

Fig. 18 - Change of performance efficiency criterion for the second option of joint operation of four power plants during the day

The best option for the power system operationis ensured by the option of joint power plants operation when changing NPP capacity from $85 \%$ to $100 \%$, PSP from $7.5 \%$ to $80 \%$, TPP from $80 \%$ to $100 \%$ and HPP- $100 \%$. Table 8 shows results of analysis of options under consideration.

Table 8 - Results of variants calculation

\begin{tabular}{|c|c|c|c|c|c|}
\hline gr. & $\begin{array}{c}\text { Types of } \\
\text { power units }\end{array}$ & $\begin{array}{l}\text { Nominal } \\
\text { capacity, } \\
\text { MW }\end{array}$ & $\begin{array}{l}\text { Change of power } \\
\text { capacityfrom the } \\
\text { nominal one }\end{array}$ & $\begin{array}{l}\text { Value of efficiency } \\
\text { ratio of the option }\end{array}$ & $\begin{array}{l}\text { Maximum capacity of the } \\
\text { marginal power unit and its } \\
\text { run time, MWh }\end{array}$ \\
\hline 1 & 2 & 3 & 4 & 5 & 6 \\
\hline .1 & $\begin{array}{l}\text { 1. NPP } \\
\text { 2. TЭC }\end{array}$ & $\begin{array}{l}1000 \\
800\end{array}$ & $\begin{array}{l}90 \% \ldots 104 \% \\
100 \% \ldots 110 \%\end{array}$ & 0,2699 & $503 / 15$ \\
\hline .2 & $\begin{array}{l}\text { 1. NPP } \\
\text { 2. TPP }\end{array}$ & $\begin{array}{l}1000 \\
800\end{array}$ & $100 \% \quad 80 \% \ldots 100 \%$ & 0,2616 & $572 / 17$ \\
\hline .3 & $\begin{array}{l}\text { 1. NPP } \\
\text { 2. TPP }\end{array}$ & $\begin{array}{l}1000 \\
800\end{array}$ & $90 \% \ldots 100 \% \quad 100 \%$ & 0,2609 & $565 / 17$ \\
\hline .1 & $\begin{array}{l}\text { 1. NPP } \\
\text { 2. TPP } \\
\text { 3. HPP }\end{array}$ & $\begin{array}{l}1000 \\
800 \\
300\end{array}$ & $\begin{array}{l}73 \% \ldots 104 \% \\
88 \% \ldots 100 \% \\
100 \%\end{array}$ & 0,3260 & $181 / 5$ \\
\hline .2 & $\begin{array}{l}\text { 1. NPP } \\
\text { 2. TPP } \\
\text { 3. HPP }\end{array}$ & $\begin{array}{l}1000 \\
800 \\
300\end{array}$ & $\begin{array}{l}73 \% \ldots 104 \% 90 \% \\
100 \%\end{array}$ & 0,3215 & $232 / 10$ \\
\hline .3 & $\begin{array}{l}\text { 1. NPP } \\
\text { 2. TPP } \\
\text { 3. HPP }\end{array}$ & $\begin{array}{l}1000 \\
800 \\
300\end{array}$ & $\begin{array}{l}73 \% \ldots 104 \% \\
70 \% \ldots 100 \% \\
35 \% \ldots 100 \%\end{array}$ & 0,2995 & $338 / 13$ \\
\hline
\end{tabular}


Автоматизація технологічних і бізнес-процесів Volume 10, Issue 4 /2017

http://www.atbp.onaft.edu.ua/

\begin{tabular}{|l|l|l|l|l|l|}
\hline 1 & \multicolumn{1}{|c|}{2} & \multicolumn{1}{|c|}{4} & \multicolumn{1}{c|}{5} & \\
\hline \multirow{4}{*}{1} & $1 . \mathrm{NPP}$ & 1000 & $85 \% \ldots 100 \%$ & 0,3319 & \\
& 2. TPP & 800 & $80 \% \ldots 100 \%$ & & \\
& $3 . \mathrm{HPP}$ & 300 & $100 \%$ & & \\
& 4. PSP & 300 & $7,5 \% \ldots 80 \%$ & 0,3235 & \\
. & $1 . \mathrm{NPP}$ & 1000 & $100 \%$ & & \\
& $2 . \mathrm{TPP}$ & 800 & $80 \% \ldots$ & & \\
& $3 . \mathrm{HPP}$ & 300 & $100 \%$ & & \\
& 4. PSP & 300 & $7,5 \% \ldots 80 \%$ & & \\
\hline
\end{tabular}

7. Conclusions

1. Efficiency of converting the primary energy into the electrical one in the power system of Ukraine can be enhancedin case if relative energy indexes would have been introduced in the framework of maneuverable power plants' properties analysis along with the economic cost indexes. Such an approach will allow balancing the conversion efficiency of primary energy. It is important that all power plants participate in the regulation of the power system balance during the day.

2. Method of efficiency analysis based on meeting the system demands from generating units allows efficient redistribution of maneuver properties between the existing power plants. Theconcept of marginalenergy cost, by which it is possible to balance the system demand for proper analysis, is used in case of discrepancy in the balance of electric power between the system demand and power generating units.

3. The best option to ensure the power system operation is provided by the option of joint power plants operation when changing NPP capacity from $85 \%$ to $100 \%$, PSP from $7.5 \%$ to $80 \%$, TPP from $80 \%$ to $100 \%$ and HPP - $100 \%$; at that, the efficiency ratio amounted to $33,19 \%$.

\section{References}

[1] N. Arsenievsky, et.al. Hydroelectric stations. Moscow: Energoatomizdat, pp. 475, 1987

[2] B. Baburin Hydroaccumulating power stations. Moscow: Energia, pp.184, 1978.

[3] M. Maksimov "The way to control a nuclear installation with VVER-1000 in maneuvering mode" in Problems of Management and Informatics, no. 3, pp. 59-74, 2015.

[4] V. Kovetsky, et.al. "Evaluation of the maneuverability of power generating plants to ensure the quality of electricity" in Problems of Energetic Energy, no. 16, pp.47-53, 2007.

[5] S.Plachkova Development of heat power and hydropower. [Online]. Available: http://energetika.in.ua/en/books/book3/part-2/section-2/2-8.

[6] O. Maksymova, et.al. "Development of the method of determining the target function", Automation of technological and business processes, vol. 9, no.2, pp. 28-35, 2017.

[7] G.Verkhivker. "About thermodynamic comparison and analysis of schemes of energy technological installations", Izvestiya high schools, ser: Power Engineering, no.11, pp. 90-93, 1986.

[8] S.Pelykh, et.al. «A method for VVER-1000 fuel rearrangement optimization taking into account both fuel cladding durability and burnup". Nuclear Engineering and Design, no.257, pp. 53-60, 2013.

\section{Література}

[1] Аршеневский Н.Н. Гидроэлектрические станции / Н.Н. Аршеневский, М.Ф. Губин, В.Я. Карелин. - М.: Энергоатомиздат, 1987. - 475 с.

[2] Бабурин Б.Л. Гидроаккумулирующие электростанции / Б.Л. Бабурин. - М.: Энергия, 1978. - 184 с.

[3] Максимов М.В. Способ управления ядерной установкой с ВВЭР-1000 в манёвренном режиме / М.В. Максимов, Т.А. Цисельская, Е.А. Кокол // Проблемы управления и информатики. - 2015. - № 3. - С. 59-74.

[4] Ковецкий В.М. Оценка маневренных возможностей электрогенерирующих установок для обеспечения качества электроэнергии / В.М. Ковецкий, М.М. Ковецкая // Проблеми загальної енергетики. - 2007. - № 16. - С.47-53.

[5] Плачкова С.Г. Развитие теплоэнергетики и гидроэнергетики. [электронный ресурс] / С.Г. Плачкова // Свободный режим доступа: http://energetika.in.ua/ru/books/book-3/part-2/section-2/2-8.

[6] Максимова О.Б. Разработка метода определения целевой функции оптимизации электростанции / О. Б. Максимова, М.М. Максимова, В.С. Силина, А. В. Орищенко // Автоматизация технологических и бизнес процессов. Том 9, выпуск 2/2017 р. 28-35.

[7] Верхикер Г.П. О термодинамическом сравнении и анализе схем энергетических технологических установок. Высшие учебные заведения «Известия». Сер .: Энергетика, 11, 90-93

[8] Пелых С.Н. Метод оптимизации перераспределения топлива ВВЭР-1000 с учетом прочности и выгорания топливной оболочки / С.Н. Пелых, М.В.Максимов, Г.Т. Паркс. // Ядерная инженерия и проектирование - 2013 . - №257. - С. 53-60. 